\title{
Influence of HLA DRB1 alleles in the susceptibility of rheumatoid arthritis and the regulation of antibodies against citrullinated proteins and rheumatoid factor
}

\author{
Alejandro Balsa*1, Arancha Cabezón², Gisela Orozco3, Tatiana Cobo', Eugenia Miranda-Carus', Miguel Ángel López-
} Nevot4, José Luis Vicario5, Emilio Martín-Mola1', Javier Martín ${ }^{3}$ and Dora Pascual-Salcedo²

\begin{abstract}
Introduction: The purpose of this study was to investigate the association between HLA-DRB1 alleles with susceptibility to rheumatoid arthritis (RA) and production of antibodies against citrullinated proteins (ACPA) and rheumatoid factor (RF).

Methods: We studied 408 patients (235 with RA, 173 non-RA) and 269 controls. ACPA, RF and HLA-DR typing were determined.

Results: We found an increased frequency of HLA DRB1 alleles with the shared epitope (SE) in ACPA-positive RA. Inversely, HLA DRB1 alleles encoding DERAA sequences were more frequent in controls than in ACPA-positive RA, and a similar trend was found for HLA DR3. However, these results could not be confirmed after stratification for the presence of the SE, probably due to the relatively low number of patients. These data may suggest that the presence of these alleles may confer a protective role for ACPA-positive RA. In RA patients we observed association between SE alleles and ACPA titers in a dose-dependent effect. The presence of HLA DR3 or DERAA-encoding alleles was associated with markedly reduced ACPA levels. No association between RF titers and HLA DR3 or DERAA-encoding alleles was found.

Conclusions: HLA DRB1 alleles with the SE are associated with production of ACPA. DERAA-encoding HLA-DR alleles and HLA DR3 may be protective for ACPA-positive RA.
\end{abstract}

\section{Introduction}

Rheumatoid arthritis (RA) is a complex autoimmune disease that develops from the combined effects of genetic and environmental factors. It is estimated that the heritability of RA accounts for about $50 \%$ to $60 \%$, and the most important genetic risk factors are the HLA class II molecules, which contribute to one third of the total genetic susceptibility $[1,2]$. There is extensive evidence for the association between certain HLA-DRB1 alleles with a conserved amino acid sequence (Q/RK/RRAA) at residues 70 to 74 in the third hypervariable region of the

\footnotetext{
* Correspondence: abalsa.hulp@salud.madrid.org

1 Servicio de Reumatología, Hospital Universitario La Paz, Paseo de la Castellana, 261, Madrid, 28046, Spain

Full list of author information is available at the end of the article
}

DR $\beta 1$ chain, the so-called shared epitope (SE), and susceptibility to and severity of RA $[3,4]$.

Autoimmunity in RA is characterized by the presence of autoantibodies. Rheumatoid factor (RF) is not specific to RA as it may be present in other diseases and in healthy older individuals [5]. In contrast, anti-citrullinated protein antibodies (ACPAs) seem to play a pivotal role in the pathogenesis of RA as they are highly specific [6], can be detected years before the onset of symptoms $[7,8]$, may predict progression to RA in patients with undifferentiated arthritis $[9,10]$, are associated with the extent of joint destruction [11], and enhance disease severity in animal models of arthritis [12].

Recent studies, including our data, have demonstrated that SE alleles are associated only with ACPA-positive RA $[13,14]$ and more strongly with ACPAs than with RA

() 2010 Balsa et al.; licensee BioMed Central Ltd. This is an open access article distributed under the terms of the Creative Commons BHoWed Central Attribution License (http://creativecommons.org/licenses/by/2.0), which permits unrestricted use, distribution, and reproduction in any medium, provided the original work is properly cited. 
itself [15], suggesting that SE alleles may influence antigen presentation pathways leading to ACPA production; SE alleles have been used to subdivide patients into distinct immunopathogenetic disease classes [4]. Whereas the association between ACPA-positive RA and SE-containing HLA class II molecules is well established, the association between HLA-DR protective versus non-predisposing alleles and ACPA-negative RA is controversial. Certain HLA-DR alleles may reduce the risk of developing RA and have been termed 'protective alleles'; however, the definition of 'protective alleles' differs depending on the study [16], making all of these results difficult to interpret. Alleles with the DERAA motif at positions 70 to 74 in the third hypervariable region have been associated with a reduced risk of RA susceptibility $[17,18]$ and less severe disease $[17,19,20]$, whereas other studies have found conflicting results regarding HLA-DR3 [21-24].

Reproducing genetic associations is very important, and studies performed in cohorts outside of North America or Northwest Europe are especially welcome due to differences in allele frequencies and genetic background. To better understand the effect of HLA in RA in the Spanish population, we investigated the association of SE-containing HLA-DRB1 alleles with susceptibility to RA and then examined the possible protective effect of HLA-DR3 and DERAA-encoding alleles. Finally, the effects of these alleles on the magnitudes of RF and ACPA production were determined.

\section{Materials and methods}

We studied 408 patients referred to the early arthritis clinic of La Paz University Hospital, Madrid. Data from this cohort have been previously reported [14]. At enrollment or during follow-up, 235 patients fulfilled the 1987 American College of Rheumatology criteria for RA and 173 were diagnosed with non-RA (mainly undifferentiated arthritis, psoriatic arthritis, reactive arthritis, and other connective tissue diseases) (Table 1). Most of the patients (91\%) in the two groups have been followed up with for more than 1 year (mean follow-up of 6.5 years). We included 269 healthy volunteers as controls. The study was approved by the La Paz University Hospital ethics committee, and all subjects were of Spanish origin and provided written informed consent.

For every patient, laboratory tests were performed on blood samples that were obtained during the patient's first visit to the clinic (before treatment with diseasemodifying antirheumatic drugs) and that were stored at $40^{\circ} \mathrm{C}$. RF was measured by nephelometry (Behring Nephelometer Analyzer II; Dade Behring, Inc., Deerfield, IL, USA) with a detection limit of $15 \mathrm{U} / \mathrm{mL}$, and ACPAs were determined by a second-generation anti-CCP-2 antibody enzyme-linked immunosorbent assay (ELISA) (Immunoscan RA Mark 2; Euro-Diagnostica, Arhem, The Netherlands) with a cutoff level of 25 arbitrary units per milliliter in accordance with the instructions of the manufacturer. The range of measurement was 0 to $1,600 \mathrm{U} /$ $\mathrm{mL}$, and all values higher than this upper limit were truncated and considered to be $1,600 \mathrm{U} / \mathrm{mL}$ for the analysis.

In DNA samples obtained from peripheral blood of controls and cases, HLA class II alleles were genotyped using a reverse dot-blot kit with sequence-specific oligonucleotide (SSO) probes (Dynal RELITM SSO HLADRB1 typing kit; Dynal Biotech, Bromborough, UK). When necessary, high-resolution typing of HLADRB1*03 samples was performed using Dynal AllSetTM SSP DRB1*03. The following alleles were considered SEpositive: DRB1"0101, "0102, "0401, "0404, "0405, "0408, "0410, "1001, and "1402. DERAA-encoding alleles were HLA-DRB1"0103, "0402, "1102, "1103, "1301, "1302, and "1304.

Statistical analysis was performed using the Statistical Package for the Social Sciences, version 10.0 (SPSS Inc., Chicago, IL, USA). Odds ratios (ORs) and proportions were compared by the chi-square test. Differences in values between groups were analyzed using Kruskal-Wallis and Mann-Whitney $U$ tests for non-parametric data.

\section{Results}

Of the 253 patients with RA, 143 (61.9\%) had ACPAs and 169 (72.5\%) RF (Table 1). The presence of both autoantibodies was strongly associated with RA (OR 27.4, 95\%

Table 1: Baseline characteristics of the patients in the study

\begin{tabular}{|c|c|c|}
\hline & $R A(n=253)$ & Non-RA $(n=173)$ \\
\hline Age in years, mean \pm standard deviation & $62 \pm 12$ & $50 \pm 14$ \\
\hline Percentage of patients who are women & 64 & 55 \\
\hline ACPA-positive, number (percentage) & $143(61.9 \%)$ & $9(5.6 \%)$ \\
\hline RF-positive, number (percentage) & $169(72.5 \%)$ & $27(15.9 \%)$ \\
\hline $\begin{array}{l}\text { Duration of symptoms in weeks, median } \\
\text { (range) }\end{array}$ & $20(3-52)$ & $15(2-52)$ \\
\hline
\end{tabular}

Percentages exclude missing data.

ACPA, anti-citrullinated protein antibody; Non-RA, other arthropathies; RA, rheumatoid arthritis; RF, IgM rheumatoid factor. 
confidence interval [CI] 14.08 to $53.34, P<0.001$ and OR $14.99,95 \%$ CI 9.18 to $24.45, P<0.001$, respectively). In non-RA patients, only $9(5.6 \%)$ and $27(15.9 \%)$ had ACPAs and RF, respectively (Table 1). Double-positivity for both ACPAs and RF was found in 137 (59.3\%) patients with RA and in $6(3.5 \%)$ patients with other arthropathies.

The distribution of our study population with respect to HLA-DRB1 genotypes and alleles is shown in Tables 2 and 3. As described previously, an increased frequency of HLA-DRB1 alleles encoding the SE was found in patients with RA compared with non-RA and control subjects (56.2\% versus $35.5 \%$, OR $2.33,95 \%$ CI 1.56 to $3.5, P<$ 0.001 and $56.2 \%$ versus $41.6 \%$, OR $1.8,95 \%$ CI 1.26 to $2.56, P=0.001$, respectively). There was a dose-dependent effect of SE-encoding HLA-DRB1 alleles: $29.8 \%$ of RA cases and $24.9 \%$ of controls had one allele (OR 1.89, 95\% CI 1.13 to 3.13), whereas $14 \%$ of RA cases and 5.6\% of controls were homozygous for SE-encoding HLADRB1 alleles (OR 3.97, 95\% CI 1.93 to 8.16) (Table 3).

The frequency of HLA-DR3 alleles was lower in the RA group than in the non-RA group (18.3\% versus $28.3 \%$, OR $0.57,95 \%$ CI 0.36 to $0.90, P=0.012)$ but was similar to that of the healthy controls $(18.3 \%$ and $19.7 \%$, respectively). No differences in the DERAA-encoding allele distribution were found among the three groups (RA 23.4\%, non-RA $26.6 \%$, and controls $26.8 \%, P=0.39$ ). Next, we studied the effect of the presence of HLA-DR3 or DERAA-encoding alleles in combination with the SE on susceptibility to RA. In the presence of one SE allele, an HLA-DR3 or DERAA-encoding allele reduced the risk of developing RA, although the effect was not statically significant (OR 1.11, 95\% CI 0.51 to 2.43 for HLA-DR3 and OR 1.04, 95\% CI 0.46 to 2.36 for DERAA-encoding alleles) (Table 3). Finally, to study the effect of the presence of HLA-DR3 or DERAA-encoding alleles on susceptibility, we combined homozygous and heterozygous patients and controls for these alleles and compared them with 'neutral' alleles. No differences in susceptibility were found for HLA-DR3 alleles (OR 1.53, 95\% CI 0.76 to 3.04) or DERAA-encoding alleles (OR $1.33,95 \%$ CI 0.74 to 2.39).

To investigate whether HLA-DR alleles were associated with different RA phenotypes, we divided our RA population according to ACPA status (Table 4). We found a higher frequency of SE alleles in ACPA-positive RA compared with healthy controls $(67.8 \%$ versus $41.6 \%$, OR 2.95 , CI 1.93 to $4.53, P<0.001$ ), but we did not observe this relationship with ACPA-negative RA patients and controls $(35.2 \%$ versus $41.6 \%, P=0.31$ ), indicating that $\mathrm{SE}$ alleles are associated with ACPA production in RA. Inversely, HLA-DRB1 alleles encoding the DERAA sequence were more frequent in controls than in ACPApositive RA patients $(26.8 \%$ versus $17.5 \%$, OR 0.58 , CI

Table 2: Distribution of HLA-DRB1 alleles in the study population

\begin{tabular}{|c|c|c|c|c|}
\hline & & $\begin{array}{c}\text { RA } \\
(n=235)\end{array}$ & $\begin{array}{c}\text { Non-RA } \\
(n=173)\end{array}$ & $\begin{array}{l}\text { Controls } \\
(n=269)\end{array}$ \\
\hline \multirow[t]{8}{*}{ SE } & *0101 & 49 (10.4\%) & $15(4.3 \%)$ & 32 (5.9\%) \\
\hline & *0102 & 17 (3.6\%) & $13(3.7)$ & $16(3.0 \%)$ \\
\hline & *0401 & 27 (5.7\%) & $10(2.9 \%)$ & $23(4.3 \%)$ \\
\hline & *0404 & $19(4 \%)$ & $7(2.0 \%)$ & 10 (1.8\%) \\
\hline & *0405 & 27 (5.7\%) & $9(2.6 \%)$ & 17 (3.1\%) \\
\hline & ${ }^{*} 0408$ & $4(0.8 \%)$ & $5(1.4 \%)$ & $8(1.5 \%)$ \\
\hline & *1001 & $18(3.8 \%)$ & $7(2.0 \%)$ & $18(3.3 \%)$ \\
\hline & *1402 & $4(0.8 \%)$ & $2(0.6 \%)$ & $3(0.5 \%)$ \\
\hline DR3 & ${ }^{*} 03$ & $43(9.1 \%)$ & $54(15.6 \%)$ & 55 (10.2\%) \\
\hline \multirow[t]{7}{*}{ DERAA } & *0103 & $4(0.8 \%)$ & $9(2.6 \%)$ & $14(2.6 \%)$ \\
\hline & ${ }^{*} 0402$ & $7(1.5 \%)$ & $6(1.7 \%)$ & 10 (1.8\%) \\
\hline & *1102 & $6(1.3 \%)$ & $5(1.4 \%)$ & $11(2.0 \%)$ \\
\hline & *1103 & $7(1.5 \%)$ & $7(2.0 \%)$ & $12(2.3 \%)$ \\
\hline & *1301 & $25(5.3 \%)$ & $20(5.8 \%)$ & $27(5.0 \%)$ \\
\hline & *1302 & $11(2.3 \%)$ & $1(0.3 \%)$ & $5(0.9 \%)$ \\
\hline & *1304 & - & - & - \\
\hline
\end{tabular}

Percentages relate to number of total alleles.

Data are presented as number and percentage of patients in each group. DERAA, HLA with DERAA-encoding alleles; DR3, HLA-DR3; Non-RA, other arthropathies; RA, rheumatoid arthritis; SE, shared epitope alleles. 
Table 3: Distribution of HLA-DRB1 genotypes

\begin{tabular}{|c|c|c|c|c|c|c|}
\hline & \multicolumn{2}{|c|}{$\begin{array}{c}\text { RA } \\
(n=235)\end{array}$} & \multicolumn{2}{|c|}{$\begin{array}{c}\text { Non-RA } \\
(n=173)\end{array}$} & \multicolumn{2}{|c|}{$\begin{array}{l}\text { Controls } \\
(n=269)\end{array}$} \\
\hline & Number & Percentage & Number & Percentage & Number & Percentage \\
\hline SE/SE & 33 & 14.0 & 7 & 4.0 & 15 & 5.6 \\
\hline SE/- & 70 & 29.8 & 31 & 17.9 & 67 & 24.9 \\
\hline SE/DR3 & 15 & 6.4 & 12 & 6.9 & 16 & 5.9 \\
\hline DR3/- & 21 & 8.9 & 25 & 14.4 & 23 & 8.6 \\
\hline DR3/DR3 & - & - & 5 & 2.9 & 2 & 0.7 \\
\hline SE/DERAA & 14 & 6.0 & 11 & 6.3 & 14 & 5.2 \\
\hline DERAA/- & 29 & 12.3 & 26 & 15.0 & 39 & 14.5 \\
\hline $\begin{array}{l}\text { DERAA/ } \\
\text { DERAA }\end{array}$ & 5 & 2.1 & 2 & 1.1 & 7 & 2.6 \\
\hline DR3/DERAA & 7 & 3.0 & 7 & 4.0 & 12 & 4.5 \\
\hline No alleles (-/-) & 41 & 17.4 & 47 & 27.1 & 74 & 27.5 \\
\hline
\end{tabular}

DERAA, HLA with DERAA-encoding alleles; DR3, HLA-DR3; Non-RA, other arthropathies; RA, rheumatoid arthritis; SE, shared epitope alleles.

0.34 to $0.96, P=0.03)$, and a similar trend was found for HLA-DR3 (19.7\% versus $12.6 \%$, OR 0.32 to $1.04, P=0.07$ ). However, the frequencies of HLA-DR3 were similar in controls and ACPA-negative RA patients, indicating that the presence of these alleles confers a protective role for ACPA-positive RA only. To further investigate whether the decreased frequencies of DERAA and HLA-DR3 alleles were secondary to the increased frequencies of $\mathrm{SE}$ in ACPA-positive RA patients, we stratified our study population by the presence of SE. A trend was observed for HLA-DR3 only, and no effect was observed for DERAA-encoding alleles, probably because of the low numbers of patients remaining (Table 5). No effect on RF of HLA-DR3 alleles (OR 1.10, 95\% CI 0.43 to $2.83, P=$ 0.8 ) or DERAA-encoding alleles (OR 0.78, 95\% CI 0.28 to 2.15, $P=0.5$ ) was observed.

In patients with RA, we observed a dose-dependent association between the presence of SE alleles and titers

Table 4: Association of HLA-DRB1 alleles with the SE, HLA-DR3, and DERAA motif with ACPA+ or ACPA-rheumatoid arthritis

\begin{tabular}{|c|c|c|c|c|c|c|c|c|}
\hline & & \multirow[t]{3}{*}{$\begin{array}{l}\text { Controls } \\
(n=269)\end{array}$} & \multicolumn{6}{|c|}{$\begin{array}{l}\text { Rheumatoid arthritis patients } \\
\qquad(\mathrm{n}=231)\end{array}$} \\
\hline & & & \multicolumn{3}{|c|}{$\operatorname{ACPA}^{+}(n=143)$} & \multicolumn{3}{|c|}{$\operatorname{ACPA}^{-}(n=88)$} \\
\hline & & & & P value & $\begin{array}{l}\text { OR, } 95 \% \\
\mathrm{CI}\end{array}$ & & P value & $\begin{array}{c}\text { OR, } 95 \% \\
\mathrm{Cl}\end{array}$ \\
\hline \multirow[t]{2}{*}{ SE } & $\begin{array}{l}\text { Absence, } \\
\mathrm{n}(\%)\end{array}$ & $157(58.4)$ & $46(32.2)$ & 0.0001 & $\begin{array}{c}2.95,1.93- \\
4.53\end{array}$ & $57(64.8)$ & 0.31 & $\begin{array}{l}0.76,0.46- \\
1.27\end{array}$ \\
\hline & $\begin{array}{l}\text { Presence, } \\
\mathrm{n}(\%)\end{array}$ & 112 (41.6) & $97(67.8)$ & & & $31(35.2)$ & & \\
\hline \multirow[t]{2}{*}{ DR3 } & $\begin{array}{l}\text { Absence, } \\
\mathrm{n}(\%)\end{array}$ & $216(80.3)$ & $125(87.4)$ & 0.07 & $\begin{array}{c}0.58,0.32- \\
1.04\end{array}$ & $63(71.6)$ & 0.10 & $\begin{array}{l}1.61,0.93- \\
2.80\end{array}$ \\
\hline & $\begin{array}{l}\text { Presence, } \\
\mathrm{n}(\%)\end{array}$ & $53(19.7)$ & $18(12.6)$ & & & $25(28.4)$ & & \\
\hline \multirow[t]{2}{*}{ DERAA } & $\begin{array}{l}\text { Absence, } \\
\mathrm{n}(\%)\end{array}$ & 197 (73.2) & $118(82.5)$ & 0.03 & $\begin{array}{c}0.58,0.34- \\
0.64\end{array}$ & $58(65.9)$ & 0.22 & $\begin{array}{l}1.41,0.84- \\
2.37\end{array}$ \\
\hline & $\begin{array}{l}\text { Presence, } \\
\mathrm{n}(\%)\end{array}$ & $72(26.8)$ & $25(17.5)$ & & & $30(34.1)$ & & \\
\hline
\end{tabular}


of RF and ACPAs (Figure 1). With two SE alleles, ACPA had a median value of 915 arbitrary units per milliliter in our ELISA (with an interquartile range [IQR] of 124 to $1,500)$. With one SE allele, there was a median ACPA of 400 (0 to 1,050), and with no alleles, it was 0 (0 to 650) ( $P$ $<0.001)$. The presence of HLA-DR3 or DERAA-encoding alleles was associated with markedly reduced ACPA levels. In the presence of HLA-DR3, ACPA had a median value of 0 (0 to 594), whereas in the absence of HLA-DR3, ACPA had a median value of $360(0$ to 1,000$)(P=0.002)$. ACPA was 0 (0 to 653) in the presence of DERAA-encoding alleles versus $310(0$ to 1,000$)$ in the absence of any DERAA-encoding alleles $(P=0.013)$. No association between RF titers and HLA-DR3 or DERAA-encoding alleles was found.

Next, we investigated the influence of DERAA-encoding alleles or HLA-DR3 together with one SE allele on RF and ACPA production. Although ACPA levels were lower in the presence of HLA-DR3 or DERAA alleles in combination with one SE allele (SE/DR3 or SE/DERAA) than in HLA-DR SE/- patients, these differences were not statistically significant: median 500 (IQR (34 to 1,250) in SE/versus 468 (0 to 760) in SE/DERAA and 32 (0 to 900) in SE/DR3 $(P=0.11)$. No similar trend for RF was found (Figure 2).

\section{Discussion}

Since 1987, when Gregersen and colleagues [25] formulated the SE hypothesis, several authors have investigated the relationship between RA and SE-encoding HLADRB1 alleles. An important discovery is that these alleles

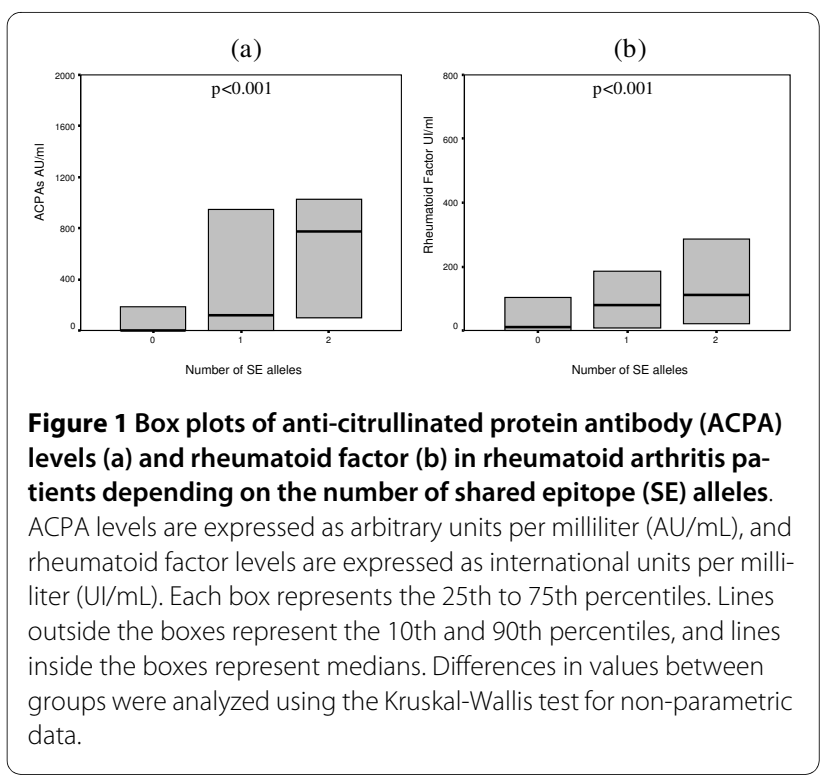

are associated with ACPAs in RA irrespectively of RF status [26]. Moreover, it was recently demonstrated that SE alleles are not associated with RA but are specific for a disease characterized by ACPAs [15]. Our results confirm these later observations as in our cohort ACPA-positive RA was strongly associated with the SE, with a gene-dose effect.

It was proposed that $\mathrm{SE}$ alleles function as immune response genes in the development of ACPAs as no differences in ACPA levels were found between RA patients with one or two SE copies [15]. In our cohort, as in other studies, a risk hierarchy in ACPA production with a sig-

Table 5: Association of HLA-DR3 and DERAA-encoding alleles stratified by the presence of shared epitope alleles with $\mathrm{ACPA}^{+}$rheumatoid arthritis

\begin{tabular}{|c|c|c|c|c|c|}
\hline & & \multirow[t]{2}{*}{$\begin{array}{l}\text { Controls } \\
(n=269)\end{array}$} & \multicolumn{3}{|c|}{$\begin{array}{l}\text { ACPA-positive RA patients } \\
\qquad(n=143)\end{array}$} \\
\hline & & & & P value & OR $(95 \% \mathrm{Cl})$ \\
\hline \multirow[t]{2}{*}{ SE-positive } & DR3-positive & $16(14.3)$ & $8(8.2)$ & 0.17 & $0.53(0.22-1.22)$ \\
\hline & DR3-negative & $96(85.7)$ & $89(91.8)$ & & \\
\hline \multirow[t]{2}{*}{ SE-negative } & DR3-positive & $37(23.6)$ & $10(21.7)$ & 0.84 & $0.90(0.40-1.98)$ \\
\hline & DR3-negative & $120(76.4)$ & $36(78.3)$ & & \\
\hline \multirow[t]{2}{*}{ SE-positive } & DERAA-positive & $14(12.5)$ & $10(10.3)$ & 0.85 & $0.58(0.34-1.90)$ \\
\hline & DERAA-negative & $98(87.5)$ & $87(89.7)$ & & \\
\hline \multirow[t]{2}{*}{ SE-negative } & DERAA-positive & $58(36.9)$ & $15(32.6)$ & 0.72 & $0.82(0.41-1.65)$ \\
\hline & DERAA-negative & $99(63.1)$ & $31(67.4)$ & & \\
\hline
\end{tabular}

Percentages relate to total SE-positive or SE-negative controls.

ACPA, anti-citrullinated protein antibody; $\mathrm{Cl}$, confidence interval; DERAA, DERAA-encoding allele; DR3, HLA-DR3; OR, odds ratio; RA, rheumatoid arthritis; $\mathrm{SE}$, shared epitope allele. 


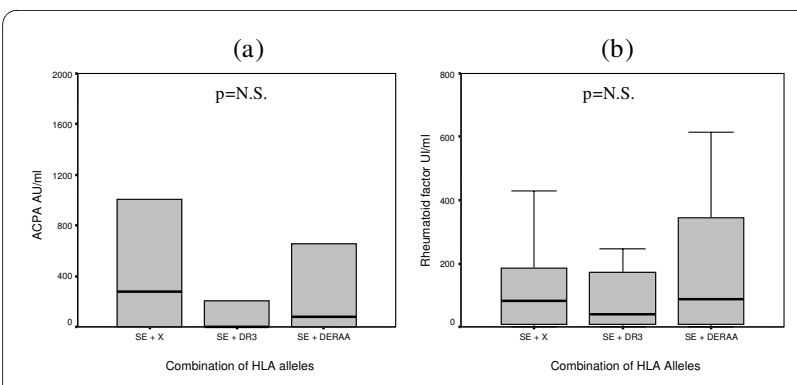

Figure 2 Box plots of anti-citrullinated protein antibody (ACPA) levels (a) and rheumatoid factor (b) in rheumatoid arthritis patients depending on the presence of one shared epitope allele (SE) combined with an HLA-DR3 or DERAA-encoding allele. ACPA levels are expressed as arbitrary units per milliliter (AU/mL), and rheumatoid factor levels are expressed as international units per milliliter $(\mathrm{UI} / \mathrm{mL})$. Each box represents the 25 th to 75 th percentiles. Lines outside the boxes represent the 10 th and 90 th percentiles, and lines inside the boxes represent medians. Differences in values between groups were analyzed using Kruskal-Wallis test for non-parametric data. N.S., not significant.

nificant dose effect in patients with two predisposing alleles was found [23]. Some SE alleles frequent in Northern Europe, such as DRB1"0401 and "0404, appear to confer a much greater degree of risk for RA [27-29] and are associated with higher levels of ACPAs than the DR1 or DR10 alleles are $[28,29]$. We have reported that, in our Spanish inception cohort, DR1 and DR4 alleles with the SE are equally represented [30] and that DR10 is a frequent SE allele in the Spanish population [31]. Therefore, it is possible that DR1 - or DR10-heterozygous patients or both have lower levels of ACPAs than DR4 patients and that DR1- or DR10-homozygous patients or both have higher levels of ACPAs.

A lack of association between ACPAs and SE alleles, when they were analyzed together, has been described, with $68 \%$ of SE-negative patients having ACPAs compared with $32 \%$ in our cohort [29]. One reason for the lack of association may be the influence of external risk factors. Tobacco exposure is a well-known environmental risk factor for the development of ACPAs in the presence of SE alleles [32] but also in their absence [33]. Increased ACPA levels in tobacco users have been reported, but these effects were relevant for DR1 and DR10 alleles only, with no significant effect on DR4 patients who had higher levels regardless of tobacco exposure [28]. Other reasons may be that not only inherited SE alleles but also noninherited SE alleles from the mother (NIMA) can be associated with RA susceptibility [34], and SE-positive cells persist in SE-negative women as a consequence of pregnancy (microchimerism) [35].

There are no well-established genetic risk factors for ACPA-negative RA [4]. Two studies have reported an increased risk of ACPA-negative RA associated with the presence of HLA-DR3 [21,22]; however, our results as well as those of two independent groups [23,24] do not support that finding. Instead, in HLA-DR3 carriers, we have found a reduced risk of ACPA-positive RA only. Another interesting finding of our study is that, as reported previously [21], HLA-DR3 carriers had lower levels of ACPAs compared with DR3 non-carriers. As this result may have been due to the reduced risk of ACPA production, we further analyzed the effect of HLA-DR3 in the presence of one SE allele and found a reduction in ACPA levels. The fact that we did not observe levels above the upper limit of detection of our ELISA may limit our capacity to demonstrate statistically significant differences.

The higher frequency of HLA-DR3 found in non-RA patients in our cohort was not unexpected. HLA-DR3 has been associated with several autoimmune diseases and with autoantibody production, mainly as part of an extended haplotype designated A1;B8;DR3 [36,37]. Whether the association with autoimmune diseases is caused by HLA-DR3 itself or by other nearby genes in linkage disequilibrium remains to be determined [21].

It has been proposed that some HLA class II alleles with a neutral or negative electric charge in their P4 pocket, such as DERAA-encoding alleles, reduce the risk of developing RA $[17,23,38]$; however, while the RA SE is consistently and reproducibly associated with RA in Caucasians, the 'protective' effect of some HLA alleles is far from fully accepted [16]. Our results are in accord with those of recent reports [27] and do not confirm that hypothesis. As with HLA-DR3, HLA DERAA-encoding alleles were associated with a reduced risk of ACPA-positive RA only, but this effect disappeared after stratification for the presence of the SE. As these same alleles have been associated with a reduced risk of RA $[17,18]$, it is possible that these results are due to the low number of patients remaining after stratification, and new studies including greater numbers of patients are needed to clarify this effect.

HLA-DR3 and HLA DERAA-encoding alleles were associated with lower levels of ACPAs, and this finding may explain the association with less severe disease $[19,20]$. The progression of joint damage has been related to levels of ACPAs, both in RA patients $[39,40]$ and in animal models of arthritis [12], so the previously described less severe disease in DERAA allele carriers may be due to lower levels of ACPAs. The reason for the reduced levels of ACPAs in the presence of HLA-DR3 or DERAA-encoding alleles is not clear, but it has been suggested that some non-associated MHC (major histocompatibility complex) class II molecules may contain P4 pockets that lack the proper size or charge to effectively accommodate the large polar side chains of citrulline, and they would be unable to bind to and present modified citrullinated peptides [41,42]. 
Overall, our data confirm the considerable complexity of HLA class II associations with RA. Many of the previously reported inconsistencies may be due not only to genetic differences or the influence of other genes in linkage disequilibrium but to the interaction with environmental risk factors. In summary, in a Spanish population, this study confirmed the previously reported observation that ACPA-positive RA is strongly associated with the HLA with the SE, with a gene-dose effect. However, our results do not support the hypothesis that HLA-DR3 or DERAA-encoding alleles protect against RA or are associated with ACPA-negative RA but rather that they only reduce the risk of ACPA-positive RA.

\section{Conclusions}

In this study, we have examined the relationship between HLA-DRB1 alleles and RA in an inception cohort of early arthritis patients, and we confirm previous evidence of an association between SE-containing HLA-DRB1 alleles and ACPA-positive RA. Our results do not support a protective effect of HLA-DR3 or DERAA-encoding alleles against RA, nor are these alleles associated with ACPAnegative RA in the Spanish population. Instead, we suggest that these alleles reduce the risk of ACPA-positive RA, but these results must be confirmed with a larger number of patients or by analyzing pooled data from reported cohorts. The presence of these alleles was associated with lower levels of ACPAs, but in the presence of one SE allele, this interaction could not be demonstrated.

\footnotetext{
Abbreviations

ACPA: anti-citrullinated protein antibody; $\mathrm{Cl}$ : confidence interval; ELISA: enzyme-linked immunosorbent assay; IQR: interquartile range; OR: odds ratio; RA: rheumatoid arthritis; RF: rheumatoid factor; SE: shared epitope; SSO: sequence-specific oligonucleotide.
}

\section{Competing interests}

The authors declare that they have no competing interests.

\section{Authors' contributions}

$A B, A C, J M, E M-M$ and DP-S participated in the design of the study, helped in the statistical analysis, and helped draft the manuscript. TC and EM-C participated in data collection and helped draft the manuscript. GO helped in the statistical analysis and participated in the design of the study. MAL-N and JLV carried out the HLA determination, analyzed and interpreted the data, and helped in the manuscript preparation. All authors read and approved the final manuscript.

\section{Acknowledgements}

We are grateful to Jesún Díez, Belén San José, and Rosario Madero for their critical comments and for providing help in the statistical analysis. This work was supported by Fundacion Mutua Madrileña PI-668 and Beca FER-Abbott 2004.

\section{Author Details}

'Servicio de Reumatología, Hospital Universitario La Paz, Paseo de la Castellana, 261, Madrid, 28046, Spain, 2 Sección de Inmunología, Hospital Universitario La Paz, Paseo de la Castellana, 261, Madrid, 28046, Spain, 3instituto de

Parasitología y Biomedicina López-Neyra, Parque Tecnológico de Ciencias de la Salud, Avenida del Conocimiento, s/n, Armilla (Granada) 18100, Spain, 4Unidad de Inmunología, Hospital Universitario Virgen de las Nieves, Avenida de las Fuerzas Armadas, 2, 18040 Granada, Spain and 5 Unidad de

Histocompatibilidad, Centro de Transfusión de la Comunidad de Madrid, Avda. de la Democracia, s/n. 28032 Madrid, Spain
Received: 4 October 2009 Revised: 31 January 2010

Accepted: 6 April 2010 Published: 6 April 2010

\section{References}

1. Deighton CM, Walker DJ, Griffiths ID, Roberts DF: The contribution of HLA to rheumatoid arthritis. Clin Genet 1989, 36:178-182.

2. Deighton $C M$, Walker $D J$ : The familial nature of rheumatoid arthritis. Ann Rheum Dis 1991, 50:62-65.

3. Seldin MF, Amos Cl, Ward R, Gregersen PK: The genetics revolution and the assault on rheumatoid arthritis. Arthritis Rheum 1999, 42:1071-1079.

4. Helm-van Mil AH van der, Huizinga TW: Advances in the genetics of rheumatoid arthritis point to subclassification into distinct disease subsets. Arthritis Res Ther 2008, 10:205.

5. Zendman AJ, Vossenaar ER, van Venrooij WJ: Autoantibodies to citrullinated (poly)peptides: a key diagnostic and prognostic marker for rheumatoid arthritis. Autoimmunity 2004, 37:295-299.

6. Schellekens GA, Visser H, de Jong BA, Hoogen FH van-den, Hazes JM, Breedveld F, van Venrooij WJ: The diagnostic properties of rheumatoid arthritis antibodies recognizing a cyclic citrullinated peptide. Arthritis Rheum 2000, 43:155-163.

7. Berglin E, Padyukov L, Sundin U, Hallmans G, Stenlund H, van Venrooij WJ, Klareskog L, Dahlqvist SR: A combination of autoantibodies to cyclic citrullinated peptide (CCP) and HLA-DRB1 locus antigens is strongly associated with future onset of rheumatoid arthritis. Arthritis Res Ther 2004, 6:R303-R308.

8. Nielen MM, van Schaardenburg D, Reesink HW, Stadt RJ van de, HorstBruinsma IE van der, de Koning MH, Habibuw MR, Vandenbroucke JP, Dijkmans BA: Specific autoantibodies precede the symptoms of rheumatoid arthritis: a study of serial measurements in blood donors. Arthritis Rheum 2004, 50:380-386.

9. van Gaalen FA, Linn-Rasker SP, van Venrooij WJ, de Jong BA, Breedveld FC, Verweij CL, Toes RE, Huizinga TW: Autoantibodies to cyclic citrullinated peptides predict progression to rheumatoid arthritis in patients with undifferentiated arthritis: a prospective cohort study. Arthritis Rheum 2004, 50:709-715

10. Visser H, le Cessie S, Vos K, Breedveld FC, Hazes JM: How to diagnose rheumatoid arthritis early. A prediction model for persistent (erosive) arthritis. Arthritis Rheum 2002, 46:357-365.

11. Meyer O, Labarre C, Dougados M, Goupille P, Cantagrel A, Dubois A, Nicaise-Roland P, Sibilia J, Combe B: Anticitrullinated protein/peptide antibody assays in early rheumatoid arthritis for predicting five year radiographic damage. Ann Rheum Dis 2003, 62:120-126.

12. Kuhn KA, Kulik L, Tomooka B, Braschler KJ, Arend WP, Robinson WH, Holers VM: Antibodies against citrullinated proteins enhance tissue injury in experimental autoimmune arthritis. J Clin Invest 2006, 116:961-973.

13. Huizinga TW, Amos Cl, Helm-van Mil AH van der, Chen W, van Gaalen FA, Jawaheer D, Schreuder GM, Wener M, Breedveld FC, Ahmad N, Lum RF, de Vries RR, Gregersen PK, Toes RE, Criswell LA: Refining the complex rheumatoid arthritis phenotype based on specificity of the HLA-DRB1 shared epitope for antibodies to citrullinated proteins. Arthritis Rheum 2005, 52:3433-3438

14. Orozco G, Pascual-Salcedo D, Lopez-Nevot MA, Cobo T, Cabezon A, Martin-Mola E, Balsa A, Martín J: Auto-antibodies, HLA and PTPN22: susceptibility markers for rheumatoid arthritis. Rheumatology (Oxford) 2008, 47:138-141.

15. Helm-van Mil AH van der, Verpoort KN, Breedveld FC, Huizinga TW, Toes $R E$, de Vries RR: The HLA-DRB1 shared epitope alleles are primarily a risk factor for anti-cyclic citrullinated peptide antibodies and are not an independent risk factor for development of rheumatoid arthritis. Arthritis Rheum 2006, 54:1117-1121.

16. Bridges SL Jr, Kelley JM, Hughes LB: The HLA-DRB1 shared epitope in Caucasians with rheumatoid arthritis: a lesson learned from tic-tac-toe. Arthritis Rheum 2008, 58:1211-1215.

17. Helm-van Mil AH van der, Huizinga TW, Schreuder GM, Breedveld FC, de Vries RR, Toes RE: An independent role of protective HLA class II alleles in rheumatoid arthritis severity and susceptibility. Arthritis Rheum 2005, $52: 2637-2644$

18. Mewar D, Coote A, Moore DJ, Marinou I, Keyworth J, Dickson MC, Montgomery DS, Binks MH, Wilson AG: Independent associations of anti-cyclic citrullinated peptide antibodies and rheumatoid factor with radiographic severity of rheumatoid arthritis. Arthritis Res Ther 2006 , 8:R128. 
19. Khani-Hanjani A, Lacaille D, Horne C, Chalmers A, Hoar DI, Balshaw R, Keown PA: Expression of QK/QR/RRRAA or DERAA motifs at the third hypervariable region of HLA-DRB1 and disease severity in rheumatoid arthritis. J Rheumatol 2002, 29:1358-1365.

20. Mattey DL, Hassell AB, Plant MJ, Cheung NT, Dawes PT, Jones PW, Thomson W, Poulton KV, Hajeer AH, Ollier WE: The influence of HLADRB1 alleles encoding the DERAA amino acid motif on radiological outcome in rheumatoid arthritis. Rheumatology (Oxford) 1999, 38:1221-1227.

21. Irigoyen $P$, Lee AT, Wener MH, Li W, Kern M, Batliwalla F, Lum RF, Massarotti E, Weisman M, Bombardier C, Remmers EF, Kastner DL, Seldin MF, Criswell LA, Gregersen PK: Regulation of anti-cyclic citrullinated peptide antibodies in rheumatoid arthritis: contrasting effects of HLADR3 and the shared epitope alleles. Arthritis Rheum 2005, 52:3813-3818.

22. Verpoort KN, van Gaalen FA, Helm-van Mil AH van der, Schreuder GM, Breedveld FC, Huizinga TW, de Vries RR, Toes RE: Association of HLA-DR3 with anti-cyclic citrullinated peptide antibody-negative rheumatoid arthritis. Arthritis Rheum 2005, 52:3058-3062.

23. Gourraud PA, Dieude P, Boyer JF, Nogueira L, Cambon-Thomsen A Mazieres B, Cornélis F, Serre G, Cantagrel A, Constantin A: A new classification of HLA-DRB1 alleles differentiates predisposing and protective alleles for autoantibody production in rheumatoid arthritis. Arthritis Res Ther 2007, 9:R27.

24. Pedersen M, Jacobsen S, Garred P, Madsen HO, Klarlund M, Svejgaard A, Pedersen BV, Wohlfahrt J, Frisch M: Strong combined gene-environment effects in anti-cyclic citrullinated peptide-positive rheumatoid arthritis: a nationwide case-control study in Denmark. Arthritis Rheum 2007, 56:1446-1453.

25. Gregersen PK, Silver J, Winchester R: The shared epitope hypothesis: an approach to understanding the molecular genetics of susceptibility to rheumatoid arthritis. Arthritis Rheum 1987, 30:1205-1213.

26. de Vries RR, Huizinga TW, Toes RE: Redefining the HLA and RA association: to be or not to be anti-CCP positive. J Autoimmun 2005, 25(Suppl):21-25.

27. Morgan AW, Haroon-Rashid L, Martin SG, Gooi HC, Worthington J, Thomson W, Barrett JH, Emery P: The shared epitope hypothesis in rheumatoid arthritis: evaluation of alternative classification criteria in a large UK Caucasian cohort. Arthritis Rheum 2008, 58:1275-1283.

28. Helm-van Mil AH van der, Verpoort KN, le CS, Huizinga TW, de Vries RR, Toes RE: The HLA-DRB1 shared epitope alleles differ in the interaction with smoking and predisposition to antibodies to cyclic citrullinated peptide. Arthritis Rheum 2007, 56:425-432.

29. Charpin C, Balandraud N, Guis S, Roudier C, Toussirot E, Rak J, Lambert N, Martin M, Reviron D, Roudier J, Auger I: HLA-DRB1*0404 is strongly associated with high titers of anti-cyclic citrullinated peptide antibodies in rheumatoid arthritis. Clin Exp Rheumatol 2008, 26:627-631.

30. Balsa A, Minaur NJ, Pascual-Salcedo D, McCabe C, Balas A, Fiddament B, Vicario JL, Cox NL, Martín-Mola E, Hall ND: Class II MHC antigens in early rheumatoid arthritis in Bath and Madrid. Rheumatology (Oxford) 2000, 39:844-849.

31. Pascual M, Nieto A, Lopez-Nevot MA, Ramal L, Mataran L, Caballero A, Alonso A, Martín J, Zanelli E: Rheumatoid arthritis in Southern Spain. Toward elucidation of a unifying role of the HLA class II region in disease predisposition. Arthritis Rheum 2001, 44:307-314.

32. Klareskog L, Padyukov L, Ronnelid J, Alfredsson L: Genes, environment and immunity in the development of rheumatoid arthritis. Curr Opin Immunol 2006, 18:650-655.

33. Verpoort KN, Voort EA Papendrecht-van der, Helm-van Mil AH van der, Zijde CM Jol-van der, van Tol MJ, Drijfhout JW, Breedveld FC, de Vries RR, Huizinga TW, Toes RE: Association of smoking with the constitution of the anti-cyclic citrullinated peptide response in the absence of HLADRB1 shared epitope alleles. Arthritis Rheum 2007, 56:2913-2918.

34. Horst-Bruinsma IE van der, Hazes JM, Schreuder GM, Radstake TR, Barrera $P$, Putte LB van de, Mustamu D, van Schaardenburg D, Breedveld FC, de Vries RR: Influence of non-inherited maternal HLA-DR antigens on susceptibility to rheumatoid arthritis. Ann Rheum Dis 1998, 57:672-675.

35. Rak JM, Maestroni L, Balandraud N, Guis S, Boudinet H, Guzian MC, Yan Z, Azzouz D, Auger I, Roudier C, Martin M, Didelot R, Roudier J, Lambert NC: Transfer of the shared epitope through microchimerism in women with rheumatoid arthritis. Arthritis Rheum 2009, 60:73-80.

36. Price P, Witt C, Allcock R, Sayer D, Garlepp M, Kok CC, French M, Mallal S, Christiansen F: The genetic basis for the association of the 8.1 ancestral haplotype (A1, B8, DR3) with multiple immunopathological diseases. Immunol Rev 1999, 167:257-274.

37. Mickelson EM, Nisperos B, Layrisse Z, Kim SJ, Thomas ED, Hansen JA: Analysis of the HLA-DRw8 haplotype: recognition by HTC typing of three distinct antigen complexes in Caucasians, Native Americans, and Orientals. Immunogenetics 1983, 17:399-410.

38. Feitsma AL, Worthington J, Helm-van Mil AH van der, Plant D, Thomson W, Ursum J, van Schaardenburg D, Horst-Bruinsma IE van der, van Rood JJ, Huizinga TW, Toes RE, de Vries RR: Protective effect of noninherited maternal HLA-DR antigens on rheumatoid arthritis development. Proc Natl Acad Sci USA 2007, 104:19966-19970.

39. Meyer O, Nicaise-Roland P, Santos MD, Labarre C, Dougados M, Goupille P, Cantagrel A, Sibilia J, Combe B: Serial determination of cyclic citrullinated peptide autoantibodies predicted five-year radiological outcomes in a prospective cohort of patients with early rheumatoid arthritis. Arthritis Res Ther 2006, 8:R40.

40. Syversen SW, Gaarder PI, Goll GL, Odegard S, Haavardsholm EA, Mowinckel P, Heijde D van der, Landewé R, Kvien TK: High anti-cyclic citrullinated peptide levels and an algorithm of four variables predict radiographic progression in patients with rheumatoid arthritis: results from a 10-year longitudinal study. Ann Rheum Dis 2008, 67:212-217.

41. Hill JA, Southwood S, Sette A, Jevnikar AM, Bell DA, Cairns E: Cutting edge: the conversion of arginine to citrulline allows for a high-affinity peptide interaction with the rheumatoid arthritis-associated HLADRB1*0401 MHC class II molecule. J Immunol 2003, 171:538-541

42. Hill J, Cairns E, Bell DA: The joy of citrulline: new insights into the diagnosis, pathogenesis, and treatment of rheumatoid arthritis. $J$ Rheumatol 2004, 31:1471-1473.

doi: 10.1186/ar2975

Cite this article as: Balsa et al., Influence of HLA DRB1 alleles in the susceptibility of rheumatoid arthritis and the regulation of antibodies against citrullinated proteins and rheumatoid factor Arthritis Research \& Therapy 2010, 12:R62

\section{Submit your next manuscript to BioMed Centra and take full advantage of:}

- Convenient online submission

- Thorough peer review

- No space constraints or color figure charges

- Immediate publication on acceptance

- Inclusion in PubMed, CAS, Scopus and Google Scholar

- Research which is freely available for redistribution 